\title{
TOXICITY OF SOME PLANT EXTRACTS AGAINST WOOD POWDER POST BEETLE, SINOXYLON SUDANICUM LESNE (Bostrychidae: Coleoptera)
}

\author{
BATT, A.M. and M.S. AHMED
}

Plant Protection Research Institute, ARC, Dokki, Giza

(Manuscript received 25 February 2013)

\begin{abstract}
The present work was conducted to evaluate the toxicity of some plant extracts against wood borers.

The obtained results showed that, average percentages of mortality of Sinoxylon sudanicum, beetles increased with increase of concentrations of different extracts of lemon grass and lantana plants.

Five statistically groups were recorded for lemon grass and lantana extracts. Highest effective group (more than $70 \%$ mortality) recorded for each volatile oil extract of lantana at $4 \%$ conc. ( $71 \%$ mortality), acetone extract of lantana at $4 \%$ conc. ( $73 \%$ mortality), chloroform extract of lemon grass at $4 \%$ conc. (77\% mortality) and ethanol extract of lantana $4 \%$ conc., (77\% mortality). The other four groups of the mortality percentages by different extracts were ranged between $1-10 \%, 12-15 \%, 26-47 \%$ and $49-65 \%$ mortality.

$\mathrm{LT}_{50}$ values obtained from lemon grass extracts showed that the higher efficacy was recorded with chloroform $4 \%, 2 \%$ and $1 \%$ Conc. (1.47, 2.71 and 3.47 days), volatile oil $4 \%$ (3.91 days) and petroleum ether $4 \%$ (5.65 days), while the shortest $\mathrm{LT}_{50}$ values for lantana extracts were obtained from ethanol 4\% (1.56 days), acetone $4 \%$ ( 1.62 days) and volatile oil (1.83 days).

Lethal concentration toxicity estimated by lowest $\mathrm{LC}_{50}$ value for lemon grass extracts was 0.79 recorded for chloroform extract followed by 0.86 (for volatile oil), 1.31 (for petroleum ether) and 2.92 (for acetone extract), these values were recorded at the $7^{\text {th }}$ day of treatment, while the lowest value of $\mathrm{LC}_{50}$ for lantana extracts was 0.001 recorded for acetone extract at $6^{\text {th }}$ and $7^{\text {th }}$ day followed by 0.05 for ethanol at $6^{\text {th }}$ day, 0.074 for volatile oil at $7^{\text {th }}$ day, 0.22 for petroleum ether at $7^{\text {th }}$ day and 3.06 for chloroform at $7^{\text {th }}$ day.
\end{abstract}

\section{INTRODUCTION}

Continued applications and intensive use of various synthetic pesticides in their different forms and several means induced in serious problems including development of pest resistance, environmental pollution, acute and chronic toxicities to human and non-target organisms. As an alternative for pesticide use, plant extracts could serve as a good control agents possessing low mammalian toxicity. 
The present work was carried out for the first time in Egypt on wood borers. The aim of this study was to evaluate the toxicity of plant extracts of two plant species namely lemon grass (Cymbopogen citrates) and lantana (Lantana camara) on wood borer, Sinoxylon sudanicum, Lesne.

\section{MATERIALS AND METHODS}

The efficacy of lemon grass (Cymbopogen citrates) and lantana (Lantana camara) extracts against wood powder post beetle. Sinoxylon sudanicum, estimated by percentage of adult morality, lethal time toxicity and lethal concentration toxicity under different concentrations of these extracts (petroleum ether, chloroform, acetone, ethanol and volatile oils).

The efficacy of lemon grass and lantana extracts against wood powder-post beetle, Sinoxylon sudanicum, was estimated by the percentages of adult mortality, lethal time toxicity and lethal concentration toxicity under different concentrations of these extracts.

\section{Tested Plants}

Two plant species of free from insecticidal contamination were used. The first was lemon grass (Cymbopogen citrates) belonging to fam. Gramineae obtained from National Research Centre, while the second species, lantana (Lantana camara) belonging to fam, Verbenaceae, was obtained from Orman Botanic Garden.

\section{Method of application}

Some pieces of healthy Poinciana wood were pulverized as saw dust and divided to piles (each $10 \mathrm{gr}$.). The concentrations (1, 2 and 4\%) of each extract and volatile oil were prepared. The piles of saw dust were treated with prepared concentrations. Five replicates was used for each concentration, the untreated check was done as solvent only.

Pile of each extract of each concentration was put in plastic tube, well compacted and provided with 20 of newly emerged beetles. The tubes were examined daily. The number of dead beetles was recorded up to 7 days after treated. The percentages of adult mortality were calculated and corrected by Abbot's formula (Abbot, 1925). The corrected mortality percentages were statistically computed using the method of Finney (1952).

The $\mathrm{LT}_{50}$ for different concentrations at 0.05 confidence limits and slope regression lines were represented and interpreted using probit analysis statistical 
method of Litchfield and Wilkoxon (1949). The efficiency or toxicity of different toxic materials was compared with standerd compound at a fixed level $\left(\mathrm{LC}_{50}\right.$ or $\left.\mathrm{LC}_{90}\right)$. The toxicity index was calculated by using sun's equation (1950) as follows:

$$
\mathrm{LC}_{50} \text { or } \mathrm{LC}_{90} \text { standard material }
$$

Sun's toxicity index $=$ $x 100$

$$
\mathrm{LC}_{50} \text { or } \mathrm{LC}_{90} \text { of tested material }
$$

While relative potency was determined as a given level (such as $\mathrm{LC}_{50}$ ) by comparing the number of folds or times of potency of the test extract with that of the least toxic one. Toxicity of the used standard material is always considered as $100 \%$.

\section{Preparation of plant extracts}

The leaves of tested plants were dried at room temperature $\left(27 \pm 1 \mathrm{c}^{\circ}\right.$ and $65-$ $80 \% \mathrm{RH}$.)for two weeks and ground in an electric mill into fine powder. Plant extrats were prepared according to the method adopted by Freedman et. al., (1979). Hundred grams of each ground plant material were successively extracted using four organic solvents of ascending polarity (Petroleum ether, chloroform, acetone and ethanol, respectively) in a soxhlet apparatus. Each extract was evaporated under vacuum pressure using a rotary evaporator. Volatile oils were obtained by waterdistillation using Clevenger apparatus, as conducted by Anderson et. al., (1980). The collected extracts weighed and stored in the refrigerator until testing, the percentage of each crude extract was calculated.

\section{Culture of insects}

Infested cuttings of mango with Bostrychid beetle, Sinoxylon sudanicum, were collected from mango orchards at Ismailia governorate. These cuttings were transported to laboratory and kept in wooden cages $(60 \times 50 \times 100 \mathrm{~cm})$, which their sides were covered with wire netting.

The culture was continuously provided with healthy cuttings of Poinciana trees to obtain permanent source of insets. The cuttings were examined daily. When the first signs of new emergence were appeared, some cuttings were broke to collect the newly beetles to be tested.

\section{Results and discussion}

Toxicity of lemon grass and lantana extracts was estimated by the mortality percentages, lethal time and lethal concentration of Sinoxylon sudanicum, adults fed on Poinciana wood treated with petroleum ether, chloroform, acetone and volatile oil extracts. The obtained results were as follows. 


\section{a) Percentages of mortality}

\section{1- Lemongrass extracts}

Mortality percentages of beetles by lemon grass extracts were recorded in Table (1). Average percentages of mortality were increased with the increase of concentration of different extracts and days after treatment. Chloroform extracts gave the highest mortality percentages (77, 63 and 52\% mortality at 4, 2 and $1 \%$ concentration), followed by volatile oil extracts (47, 37 and $27 \%$ mortality at 4,2 and $1 \%$ concentration), while the lowest percentages of mortality recorded by ethanol extract (13, 9 and $1 \%$ mortality at 4,2 and $1 \%$ concentration). Highly significant differences were recorded between percentages of mortality of Sinoxylon sudanicum, adults at tested concentrations and different days except chloroform extract which detected insignificant differences at different days of treatments, while ethanol extract show significant differences between mortality percentages during treatment period.

In this respect, Hewady et. al., (1994) evaluated oils extracted from four plant species against newly hatched larvae of cotton bollworms, Pectinophora gossypiella (Sand) and Earias insvlana (Boisd). They indicated that lemongrass is toxic to the larvae of two species.

Recently, Rajapakse and Ratrasekera (2008) obtained plant oils from leaves of lemongrass and bioassayed under laboratory conditions for their ability to stored legumes from damage by cowpea weevil (Callosobruchus maculates) and adzuki bean seed weevil (Callosobruchus chinensis) showed some bioactivity, and caused significant adult mortality and high mortality effect.

Lemon grass ( $C$. citrates) extracts showed different effects such as, larvicidal activity to larvae of C. albiceps (Morsy et. al., 1998), repellent ability against Sitophilus zeamis weevils (Shenge et. al., 2002), larvicidal properties against the mosquito, Aedes aegypti L. (Calvacenti et. al., 2004), elicited repellency of 40-60\% and antifeedant properties to banana weevils Cosmopolites sordidas (Inyang and Emosairue, 2005). 
Table. 1. Average and range of mortality percentages of Sinoxylon sudanicum beetles reared on Poinciana wood treated by three concentrations of different lemongrass extracts during seven days.

\begin{tabular}{|c|c|c|c|c|c|}
\hline \multirow{2}{*}{ Conc. \% } & \multicolumn{5}{|c|}{ Percentage of mortality } \\
\cline { 2 - 6 } $1 \%$ & Petroleum ether & Chloroform & Acetone & Ethanol & Volatile oil \\
\hline \multirow{2}{*}{$2 \%$} & $25 \pm 0.61$ & $10 \pm 0.29$ & $49 \pm 0.88$ & $50 \pm 0.71$ & $53 \pm 0.62$ \\
\cline { 2 - 6 } & $3-68$ & $4-32$ & $12-92$ & $10-76$ & $20-88$ \\
\cline { 2 - 6 } & $29 \pm 0.59$ & $16 \pm 0.32$ & $62 \pm 0.86$ & $58 \pm 0.75$ & $65 \pm 0.60$ \\
\hline \multirow{2}{*}{$4 \%$} & $5-68$ & $8-40$ & $12-96$ & $18-92$ & $32-96$ \\
\cline { 2 - 6 } & $34 \pm 0.68$ & $25 \pm 0.49$ & $73 \pm 0.58$ & $77 \pm 0.64$ & $71 \pm 0.61$ \\
\hline \multirow{2}{*}{ F. Conc. Days } & $8-80$ & $10-56$ & $44-96$ & $32-96$ & $33-96$ \\
\cline { 2 - 6 } & 4.72 & 11.48 & 30.29 & 46.66 & 52.71 \\
\hline L.S.D. Conc. 0.05 & 15.16 & 6.47 & 14.49 & 13.00 & 9.92 \\
\hline L.S.D. Conc. 0.01 & 11.36 & 9.08 & 14.48 & 13.55 & 12.62 \\
\hline L.S.D. Days 0.05 & -- & 12.46 & 19.85 & 18.18 & 17.31 \\
\hline L.S.D. Days 0.01 & 15.03 & 12.01 & 19.15 & 17.53 & 16.70 \\
\hline
\end{tabular}

\section{2- Lantana extracts}

Data in Table (2) show the mortality percentages of Sinoxylon sudanicum, beetles reared on Poinciana wood treated with different extracts of lantana. Average percentages of mortality increased with the increase of concentration of different extracts and days after treatment. Ethanol extracted at $4 \%$ concentration gave the highest percentage of mortality (77\%) followed by Acetone $4 \%$ (73\% mortality) and volatile oil ( $71 \%$ mortality) while the lowest percentage recorded for chloroform extract at $1 \%$ (10\% mortality), $2 \%$ (16\% mortality), and 4\% ( $25 \%$ mortality).

Table. 2. Average and range of mortality percentages of Sinoxylon sudanicum beetles reared on Poinciana wood treated by three concentrations of different lantana extracts during seven days.

\begin{tabular}{|c|c|c|c|c|c|}
\hline \multirow{2}{*}{ Conc. \% } & \multicolumn{5}{|c|}{ Percentage of mortality } \\
\cline { 2 - 6 } & $\begin{array}{c}\text { Petroleum } \\
\text { ether }\end{array}$ & Chloroform & Acetone & Ethanol & \multirow{2}{*}{ Volatile oil } \\
\hline \multirow{2}{*}{$1 \%$} & $26 \pm 0.41$ & $52 \pm 0.37$ & $12 \pm 0.12$ & $1 \pm 0.03$ & $27 \pm 0.35$ \\
\cline { 2 - 6 } & $8-52$ & $24-64$ & $8-20$ & $1-4$ & $16-56$ \\
\hline \multirow{2}{*}{$2 \%$} & $30 \pm 0.43$ & $63 \pm 0.46$ & $33 \pm 0.41$ & $9 \pm 0.15$ & $37 \pm 0.42$ \\
\cline { 2 - 6 } & $12-56$ & $36-64$ & $8-48$ & $4-20$ & $20-64$ \\
\hline \multirow{2}{*}{$4 \%$} & $41 \pm 0.54$ & $77 \pm 0.51$ & $36 \pm 0.38$ & $13 \pm 0.15$ & $47 \pm 0.65$ \\
\cline { 2 - 6 } & $24-79$ & $44-92$ & $16-52$ & $8-24$ & $24-84$ \\
\hline \multirow{2}{*}{ F. Conc. Days } & 19.84 & 4.99 & 30.23 & 24.27 & 19.51 \\
\hline & 9.21 & 0.50 & 4.59 & 3.37 & 4.87 \\
\hline L.S.D. Conc. 0.05 & 9.88 & 39.46 & 9.21 & 3.78 & 13.28 \\
\hline L.S.D. Conc. 0.01 & 13.55 & -- & 12.63 & 5.19 & 18.22 \\
\hline L.S.D. Days 0.05 & 13.07 & N.S & 12.18 & 5.01 & 17.57 \\
\hline L.S.D. Days 0.01 & 17.92 & -- & 16.71 & -- & 24.10 \\
\hline
\end{tabular}

Highly significant differences were proved between percentages of mortality and each of different concentrations and days after treatment. 
Pandy et. al., (1983) found that dried leaves of Lantana camara var. aculeate gave 52.36 - 61.40\% mortality to Aphis gossypii Glov., also Pandy et. al., (1987) found that Lantana camara extract showed $66.6 \%$ mortality against the aphid Lipaphis erysimi. Mukhtar et. al., (1991) studied the efficacy of some plant extracts against Ailanthus web worm, Atteva fabriciella. They found that $5.0 \%$ ethanolic extract of Lantana camara caused $66.66 \%$ mortality Dwivedi and Seema (2003) found that extract of Lantana camara flower against Corcyra cepholonica resulting in $87.32 \%$ of the population control of the rice moth. El-Hefny et. al., (2011) indicated that lantana in acetone caused the higher percentage reduction of Planococeus citri (Risso) which ranged from (34.59-79.84\%), (38.1 - 90.48\%) and (32.69-92.30\%) for concentrations 3,4 and $5 \%$, respectively.

Comparison between the effect of lemon grass and lantana extracts Table 3, showed that the percentages of mortality of Sinoxylon sudanicum adults obtained by petroleum ether and chloroform extracts of lemon grass proved higher than from the others obtained by lantana extracts while acetone, ethanal and volatile oil extracts for lantana gave a high mortality percolates from the same extracts of lemon grass.

Five statistical groups were receded for lemon grass and lantana as follows:

a)Within $1-10 \%$ mortality.

b) Within $1-10 \%$ mortality.

c) Within $1-10 \%$ mortality.

d) Within $1-10 \%$ mortality.

e) Within $1-10 \%$ mortality.

Table. 3. Mortality percentages of Sinoxylon sudanicum adults recorded at different concentrations of lemongrass and lantana extracts.

\begin{tabular}{|c|c|c|c|c|c|c|c|c|c|c|}
\hline \multirow{3}{*}{$\begin{array}{l}\text { Concent- } \\
\text { ration } \%\end{array}$} & \multicolumn{10}{|c|}{ Average percentages of mortality } \\
\hline & \multicolumn{2}{|c|}{ Petroleum ether } & \multicolumn{2}{|c|}{ Chloroform } & \multicolumn{2}{|c|}{ Acetone } & \multicolumn{2}{|c|}{ Ethanol } & \multicolumn{2}{|c|}{ Volatile oil } \\
\hline & L.g & L.c. & L.g & L.C. & L.g & L.c. & L.g & L.C. & L.g & L.c. \\
\hline $1 \%$ & $26 c$ & $25 b$ & $52 \mathrm{~d}$ & $10 \mathrm{a}$ & $12 \mathrm{~b}$ & $49 \mathrm{~d}$ & $1 \mathrm{a}$ & $50 \mathrm{~d}$ & $27 c$ & $53 d$ \\
\hline $2 \%$ & $30 \mathrm{c}$ & $29 \mathrm{c}$ & $63 \mathrm{~d}$ & $16 \mathrm{~b}$ & $33 c$ & $62 \mathrm{~d}$ & $9 \mathrm{a}$ & $58 d$ & $37 c$ & $65 d$ \\
\hline $4 \%$ & $4 c$ & $34 \mathrm{c}$ & $77 \mathrm{e}$ & $25 \mathrm{~b}$ & $36 c$ & $73 \mathrm{e}$ & $13 \mathrm{~b}$ & $77 \mathrm{e}$ & $47 c$ & $71 \mathrm{e}$ \\
\hline
\end{tabular}

Values of some letter are unsignificant. 


\section{B. Lethal time toxicity (LTm)}

\section{1- Lemongrass extracts}

The lethal time toxicity of tested lemongrass extracts at different concentrations were presented in Table (4). At concentrations 1, 2 and 4\% the slope values of toxicity lines were 2.128, 1.804, 1.539 (for Petroleum ether), 0.912, 2.160, 2.186 (for chloroform), $0.822,1.387,1.704$ (for Acetone) and 0.988, 1.078, 2.291 (for Volatile oil).

Among all the assayed materials, shorter $\mathrm{LT}_{50}$ values which definitely indicated to higher efficacy when the beetles reared on Poinciana wood treated by lemongrass extracted in chloroform at 4, 2 and $1 \%$ Conc. (1.47, 2.71 and 3.47 days), volatile oil $4 \%$ (3.91 days) and petroleum ether $4 \%$ (5.65 days), while the $\mathrm{LT}_{50}$ values for remaining treatments could be arranged in descending order as acetone $4 \%(6.20$ days), acetone $2 \%$ ( 6.99 days), volatile oil $2 \%$ ( 7.28 days), petroleum ether $2 \%$ ( 8.72 days), petroleum ether $1 \%$ (8.78 days) and volatile oil $1 \%$ (13.26 days) while the least efficacy (longest $\mathrm{LT}_{50}$ value) was obtained from acetone extracted $1 \%$ (84.09 days). In this respect, values of $\mathrm{LT}_{90}$ were arranged as follows: chloroform $4 \%$ and $2 \%$ (5.69 and 10.62 days), volatile oil 4\% (14.18 days), Acetone 4\% (33.63 days), petroleum ether $1 \%, 4 \%$ and $2 \%$ (35.13, 38.44 and 44.75 days), acetone $2 \%$ (58.74 days), chloroform $1 \%$ (88.22 days), volatile oil $2 \%$ (100 days) and each acetone $1 \%$ and volatile oil $\%$ (>100 days).

The toxicity index revealed that most potent compounds (T.I $=100 \%)$ recorded for petroleum ether $4 \%$, chloroform $4 \%$, acetone $4 \%$ ethanol $4 \%$ and volatile oil $4 \%$, while the least values of T.I., were $7.37 \%$ and $29.49 \%$ recorded for acetones $1 \%$ and volatile oil $1 \%$ mortality

Table. 4. Lethal time toxicity (LTn) of three concentrations for different extracts of lemon grass on Sinoxylon sudanicum beetle.

\begin{tabular}{|c|c|c|c|c|c|c|c|c|c|c|c|c|c|}
\hline \multirow{2}{*}{\multicolumn{2}{|c|}{ Toxicity items }} & \multicolumn{3}{|c|}{ Petroleum ether } & \multicolumn{3}{|c|}{ Chloroform } & \multicolumn{3}{|c|}{ Acetone } & \multicolumn{3}{|c|}{ Volatile oil } \\
\hline & & $1 \%$ & $2 \%$ & $4 \%$ & $1 \%$ & $2 \%$ & $4 \%$ & $1 \%$ & $2 \%$ & $4 \%$ & $1 \%$ & $2 \%$ & $4 \%$ \\
\hline \multicolumn{2}{|c|}{ Slope \pm S.C } & $\begin{array}{c}2.128 \\
\pm \\
0.266\end{array}$ & $\begin{array}{c}1.804 \\
\pm \\
0.236\end{array}$ & $\begin{array}{c}1.539 \\
\pm \\
0.198\end{array}$ & $\begin{array}{c}0.912 \\
\pm \\
0.177\end{array}$ & $\begin{array}{c}2.16 \\
\pm \\
0.196\end{array}$ & $\begin{array}{c}2.186 \\
\pm \\
0.200\end{array}$ & $\begin{array}{c}0.822 \\
\pm \\
0.242\end{array}$ & $\begin{array}{c}1.387 \\
\pm \\
0.199\end{array}$ & $\begin{array}{c}1.746 \\
\pm \\
0.210\end{array}$ & $\begin{array}{c}0.988 \\
\pm \\
0.198\end{array}$ & $\begin{array}{c}1.078 \\
\pm \\
0.189\end{array}$ & $\begin{array}{c}2.291 \\
\pm \\
0.21 \\
\end{array}$ \\
\hline \multirow[b]{2}{*}{$L T_{50}$} & Value & 8.78 & 8.72 & 5.65 & 3.47 & 2.71 & 1.47 & 84.09 & 6.99 & 6.20 & 13.26 & 7.28 & 3.91 \\
\hline & Range & $\begin{array}{c}7.35 \\
- \\
11.51 \\
\end{array}$ & $\begin{array}{c}7.18 \\
- \\
11.84 \\
\end{array}$ & $\begin{array}{c}7.27 \\
- \\
10.88\end{array}$ & $\begin{array}{c}2.69 \\
- \\
4.49 \\
\end{array}$ & $\begin{array}{c}2.40 \\
- \\
3.02 \\
\end{array}$ & $\begin{array}{c}1.22 \\
- \\
1.71\end{array}$ & $\begin{array}{c}26.20 \\
- \\
>100\end{array}$ & $\begin{array}{c}5.71 \\
- \\
9.55\end{array}$ & $\begin{array}{c}5.32 \\
- \\
7.65 \\
\end{array}$ & $\begin{array}{c}12.05 \\
- \\
22.71 \\
\end{array}$ & $\begin{array}{c}5.63 \\
- \\
11.37\end{array}$ & $\begin{array}{c}2.68 \\
- \\
6.04 \\
\end{array}$ \\
\hline \multirow[b]{2}{*}{$\mathrm{LT}_{90}$} & Value & 35.13 & 44.75 & 38.44 & 88.22 & 10.62 & 5.69 & $>100$ & 58.74 & 33.63 & $>100$ & 100 & 14.18 \\
\hline & Range & $\begin{array}{c}22.88 \\
- \\
70.69 \\
\end{array}$ & $\begin{array}{c}27.02 \\
- \\
103.85 \\
\end{array}$ & $\begin{array}{c}24.66 \\
- \\
91.76 \\
\end{array}$ & $\begin{array}{c}35.21 \\
- \\
>100 \\
\end{array}$ & $\begin{array}{c}8.71 \\
- \\
13.94 \\
\end{array}$ & $\begin{array}{c}4.90 \\
- \\
6.91 \\
\end{array}$ & $\begin{array}{c}>100 \\
- \\
>100 \\
\end{array}$ & $\begin{array}{c}31.50 \\
- \\
>100 \\
\end{array}$ & $\begin{array}{c}21.83 \\
- \\
66.96 \\
\end{array}$ & $\begin{array}{c}>100 \\
- \\
>100 \\
\end{array}$ & $\begin{array}{c}45.85 \\
- \\
>100 \\
\end{array}$ & $\begin{array}{c}15.41 \\
- \\
54.58 \\
\end{array}$ \\
\hline \multicolumn{2}{|c|}{ Index } & 64.35 & 64.79 & 100.0 & 42.36 & 54.24 & 100.0 & 7.37 & 88.70 & 100.0 & 29.99 & 53.71 & 100.0 \\
\hline
\end{tabular}




\section{2- Lantare extracts}

Data illustrated in Table (5) showed the lethal time toxicity of tested lemon grass extracts at different concentrations.

The slope values of the toxicity lines for different extracts of lantana at 1, 2 and $4 \%$ concentrations were 3.084, 2.952 and 3.082 (for petroleum ether), 1.053, 2.104 and 1.974 (for chloroform), 3.238, 3.475 and 2.154 (for acetone), 2.157, 3.221 and 2.525 (for ethand) and 5.059, 2.078 and 2.353 (for volatile oil), respectively. The shortest $\mathrm{LT}_{50}$ values (highest efficacy) were obtained from ethanol $4 \%$ ( 1.56 days), acetone 4\% (1.62 days) and volatile oil 4\% (1.83 days), while the least efficacy (longest $\mathrm{LT}_{50}$ values) were obtained from chloroform at $2 \%$ (14.79 days) and $1 \%$ (40.63 days). According $\mathrm{LT}_{90}$, the shortest values recorded to ethanol $4 \%$ (5.02 days), acetone $2 \%$ (6.20 days), 4\% (6.38 days) and volatile oil $4 \%$ (6.42 days), while the longest values recorded for chloroform extract at 4\% (37.83 days, 2\% ( 60.13 days) and $1 \%$ (>100 days). As regard to the toxicity index, it is obvious that $4 \%$ concentration of different lantana extracts $(T . I=100 \%)$ drive the concentrations of all tested extracts. Presently El-Hefny et. al., (2011) other found that $\mathrm{LT}_{50}$ value obtained from treatment $P$. citri by lantana extracted in acetone at $4 \%$ Conc. Recorded 2.56 days. 
Table. 5. Lethal time toxicity (LTn) of three concentrations for different extracts of lantana on Sinoxylon sudanicum beetle.

\begin{tabular}{|c|c|c|c|c|c|c|c|c|c|c|c|c|c|c|c|c|}
\hline \multicolumn{2}{|c|}{ Toxicity items } & \multicolumn{3}{|c|}{ Petroleum ether } & \multicolumn{3}{|c|}{ Chloroform } & \multicolumn{3}{|c|}{ Acetone } & \multicolumn{3}{|c|}{ Ethanol } & \multicolumn{3}{|c|}{ Volatile oil } \\
\hline & & $1 \%$ & $2 \%$ & $4 \%$ & $1 \%$ & $2 \%$ & $4 \%$ & $1 \%$ & $2 \%$ & $4 \%$ & $1 \%$ & $2 \%$ & $4 \%$ & $1 \%$ & $2 \%$ & $4 \%$ \\
\hline \multirow{3}{*}{\multicolumn{2}{|c|}{ Slope \pm S.C }} & 3.084 & 2.952 & 3.082 & 1.053 & 2.104 & 1.974 & 3.238 & 3.475 & 2.154 & 2.157 & 3.221 & 2.525 & 2.059 & 2.078 & 2.253 \\
\hline & & \pm & \pm & \pm & \pm & \pm & \pm & \pm & \pm & \pm & \pm & \pm & \pm & \pm & \pm & \pm \\
\hline & & 0.362 & 0.290 & 0.299 & 0.251 & 0.348 & 0.248 & 0.246 & 0.238 & 0.197 & 0.199 & 0.234 & 0.215 & 0.197 & 0.192 & 0.200 \\
\hline \multirow{4}{*}{$\mathrm{LT}_{50}$} & Value & 6.74 & 6.02 & 5.06 & 40.63 & 14.79 & 8.49 & 3.67 & 2.65 & 1.62 & 3.23 & 3.10 & 1.56 & 3.27 & 2.13 & 1.83 \\
\hline & & 5.99 & 5.56 & 5.05 & 31.82 & 11.77 & 7.66 & 2.32 & 2.44 & 0.83 & 2.89 & 2.51 & 1.10 & 2.30 & 1.30 & 1.57 \\
\hline & Range & - & - & - & - & - & - & - & - & - & - & - & - & - & - & - \\
\hline & & 11.28 & 9.45 & 8.58 & 94.95 & 37.89 & 11.84 & 5.46 & 2.86 & 2.00 & 3.59 & 3.68 & 1.90 & 4.45 & 2.71 & 2.07 \\
\hline \multirow{4}{*}{$\mathrm{LT}_{90}$} & Value & 17.53 & 16.37 & 15.53 & $>100$ & 60.13 & 37.83 & 9.14 & 6.20 & 6.38 & 12.68 & 7.74 & 5.02 & 13.72 & 8.81 & 6.41 \\
\hline & & 15.88 & 15.23 & 14.53 & $>100$ & 55.17 & 30.12 & 8.29 & 5.60 & 5.36 & 10.19 & 6.65 & 4.13 & 12.15 & 7.55 & 5.55 \\
\hline & Range & - & - & - & - & - & - & - & - & - & - & - & - & - & - & - \\
\hline & & 51.13 & 44.47 & 38.26 & $>100$ & 100.0 & 98.99 & 29.10 & 7.02 & 13.53 & 17.12 & 10.95 & 7.12 & 36.32 & 19.24 & 7.75 \\
\hline \multicolumn{2}{|c|}{ Index } & 88.43 & 99.0 & 100.0 & 20.90 & 57.40 & 100.0 & 44.14 & 61.13 & 100.0 & 48.30 & 50.32 & 100.0 & 55.96 & 85.82 & 100.0 \\
\hline
\end{tabular}




\section{C- Lethal concentration toxicity}

\section{1- Lemon grass extracts}

Lethal concentration toxicity of seven days after treatment with different lemon grass extracts is demonstrated in Table (6).

The lowest value of $\mathrm{LC}_{90}$ was $0.79 \mathrm{ppm}$ recorded for chloroform extract followed by 0.86 (for volatile oil), $1.31 \mathrm{ppm}$ (for petroleum ether), $2.92 \mathrm{ppm}$ (for acetone extract). These values were recorded at the $7^{\text {th }}$ day of treatment.

At $\mathrm{LC}_{90}$ level the range of lowest values was between $3.33 \mathrm{ppm}$ (for chloroform at $7^{\text {th }}$ day) to $17.97 \mathrm{ppm}$ (for acetone at $6^{\text {th }}$ day).

The recorded values of slope showed that the range of the slope values was between 0.212 (petroleum ether at $4^{\text {th }}$ day) and 0.221 (volatile oil at $2^{\text {nd }}$ day) to 2.057 (chloroform at $7^{\text {th }}$ day) and 2.136 (volatile oil at $6^{\text {th }}$ day).

The standard value of toxicity index $100 \%$ recorded at the $7^{\text {th }}$ day for all extracts, the lowest value was recorded at the $1^{\text {st }}$ day for chloroform (11.70), Acetone (2.64) and volatile oil $(0.01)$, while it was 0.001 for petroleum ether at $4^{\text {th }}$ day. The most potent extract was 1455.92 for as toxic as the $4^{\text {th }}$ day for petroleum ether and it was 5675.65 fold as toxic as the $2^{\text {nd }}$ day for volatile oil extract, while potency of chloroform, acetone extract was 8.54 and 37.86 fold as toxic as the $1^{\text {st }}$ day.

Marsy et. al., (1998) found that lemon grass showed larvicidal activity with the $\mathrm{LC}_{50}$ ranging between $135 \mathrm{ppm}$ (ethanol extract) and $570 \mathrm{ppm}$ (chloroform extract). 
Table. 6. Lethal concentration toxicity (LCn) of seven days treatment with different extracts of lemon grass on Sinoxylon sudanicum beetle.

\begin{tabular}{|c|c|c|c|c|c|c|}
\hline Extract & & Slope & $\mathrm{LC}_{50}(\mathrm{ppm})$ & $\mathrm{LC}_{90}(\mathrm{ppm})$ & Inde $X$ & No. of folds \\
\hline \multirow[t]{3}{*}{ Petroleum ether } & Av. $\pm \mathrm{Se}$ & $0.913 \pm 0.199$ & $288.07 \pm 629.91$ & $3184.02 \pm 1773.29$ & 25.05 & --- \\
\hline & Range & $0.212-1.796$ & $1.31-1907.25$ & $17.6->10000$ & $0.001-100$ & $1-1455.92$ \\
\hline & Day & $4^{\text {th }} \ldots . .1^{\text {st }}$ & $7^{\text {th }} \ldots . .4^{\text {th }}$ & $7^{\text {th }} \ldots . .4^{\text {th }}$ & $4^{\text {th } \ldots . . .7^{\text {th }}}$ & $4^{\text {th }} \ldots . . .7^{\text {th }}$ \\
\hline \multirow[t]{3}{*}{ Chloroform } & $\mathrm{Av} . \pm \mathrm{Se}$ & $1.457 \pm 2.645$ & $2.01 \pm 0.82$ & $43.08 \pm 22.49$ & 68.26 & --- \\
\hline & Range & $0.732-2.057$ & $0.79-6.75$ & $3.33-150.74$ & $11.70-100$ & $1-8.54$ \\
\hline & Day & $2^{\text {nd }} \ldots . .7^{\text {th }}$ & $7^{\text {th }} \ldots .1^{\text {st }}$ & $7^{\text {th }} \ldots . .2^{\text {nd }}$ & $1^{\text {st }} \ldots . .7^{\text {th }}$ & $1^{\text {st } \ldots . . .7^{\text {th }}}$ \\
\hline \multirow[t]{3}{*}{ Acetone } & $\mathrm{Av} . \pm \mathrm{Se}$ & $1.287 \pm 2.969$ & $23.66 \pm 14.97$ & $1072.56 \pm 909.35$ & 52.24 & --- \\
\hline & Range & $0.725-1.635$ & $2.92-110.54$ & $17.97-6485.56$ & $2.64-100$ & $1-37.86$ \\
\hline & Day & $1^{\text {st } \ldots . .6^{\text {th }}}$ & $7^{\mathrm{th}} \ldots . .1^{\mathrm{st}}$ & $6^{\mathrm{th}} \ldots \ldots 1^{\mathrm{st}}$ & $1^{\mathrm{st}} \ldots . .7^{\text {th }}$ & $1^{\text {st } \ldots . . .6^{\text {th }}}$ \\
\hline \multirow[t]{3}{*}{ Volatile oil } & $\mathrm{Av} . \pm \mathrm{Se}$ & $0.943+0.249$ & $729.01+692.24$ & $4316.57+2009.46$ & 25.31 & -- \\
\hline & Range & $0.221-2.136$ & $0.86-4881.04$ & $7.60->1000$ & $0.01-100$ & $1-5675.63$ \\
\hline & Day & $2^{\text {nd }} \cdots . .6^{\text {th }}$ & $7^{\text {th }} \ldots . .2^{\text {nd }}$ & $7^{\text {th }} \ldots .1^{\text {st }}$ & $1^{\text {st } \ldots . . .7^{\text {th }}}$ & $2^{\text {nd }} \ldots . .7^{\text {th }}$ \\
\hline
\end{tabular}




\section{2- Lantana extracts}

The obtained results in Table (7) showed that the lowest value of $\mathrm{LC}_{50}$ was $0.001 \mathrm{ppm}$ recorded for acetone extract (at $6^{\text {th }}$ and $7^{\text {th }}$ day) followed by $0.05 \mathrm{ppm}$ for ethanol (at $6^{\text {th }}$ day) $0.074 \mathrm{ppm}$ for volatile oil (at $7^{\text {th }}$ day), $0.22 \mathrm{ppm}$ for petroleum ether (at $7^{\text {th }}$ day) and 3.06 ppm for chloroform (at $7^{\text {th }}$ day). At $L C_{90}$ level, the range of lowest values was between $1.181 \mathrm{ppm}$ for volatile oil (at $7^{\text {th }}$ day) and $31.86 \mathrm{ppm}$ for chloroform (at $6^{\text {th }}$ day).

The recorded values of slope showed that these values were between 0.40 for acetone (at $6^{\text {th }}$ day) to 0.601 for volatile oil (at $1^{\text {st }}$ day).

The standard value of toxicity index $100 \%$ recorded for all extracts at $7^{\text {th }}$ day, the range of lowest values was between $0.002 \%$ (for chloroform at $1^{\text {st }}$ day) and $0.47 \%$ (for ethand at $6^{\text {th }}$ day). The extracts of chloroform, acetone, ethanol and volatile oil recorded $462.93,5580,25.12$ and 257.70 fold as toxic as the $1^{\text {st }}$ day, while the petroleum ether extract showed 1605.72 fold as toxic as the $3^{\text {rd }}$ day.

Adebayo an Gbolade (1994) evaluated the suitability of some plant products (leaf powder and volatile oils) in protecting cowpea seeds from attak by Callosobruchus maculates during storage at a range of $0.5-4 \mathrm{gm}$ powder and $05.30 \mu \mathrm{l}$ for 0.1 oils from Lantana camara and Cymbopogen citrates were more potent than their respective powders in reducing or inhibting oviposition and adult emergence.

Reddy et. al., (1991) found that acetone extract of Lantana camara at a concentration of $680,340,170$ and $85 \mathrm{Mg} / \mathrm{ml}$. exhibited high antifeedant and repellent activity against the furniture beetle, Sinoxylon sudanicum . 
Table. 7. Lethal concentration toxicity ( $\mathrm{LCn}$ ) of seven days after treatment with different extracts of lantana on Sinoxylon sudanicum beetle.

\begin{tabular}{|c|c|c|c|c|c|c|}
\hline Extract & & Slope & $\mathrm{LC}_{50}(\mathrm{ppm})$ & $\mathrm{LC}_{90}(\mathrm{ppm})$ & Inde $X$ & No. of folds \\
\hline \multirow[t]{3}{*}{ Petroleum ether } & Range & $0.420-1.208$ & $0.22-3609.26$ & $24.87->10000$ & $0.01-100$ & $1-1605.72$ \\
\hline & Av. $\pm \mathrm{Se}$ & $0.743 \pm 0.11$ & $550.25 \pm 510.21$ & $2457.61 \pm 1299.70$ & 15.66 & --- \\
\hline & Day & $3^{\text {rd }} \ldots .2^{\text {nd }}$ & $7^{\text {th }} \ldots .3^{\text {rd }}$ & $7^{\text {th }} \ldots .3^{\text {rd }}$ & $3^{\text {rd }} \ldots .7^{\text {th }}$ & $3^{\text {rd }} \ldots . .7^{\text {th }}$ \\
\hline \multirow[t]{3}{*}{ Chloroform } & Range & $0.531-1.612$ & $3.06-1416.58$ & $31.86-26442.76$ & $0.002-100$ & $1-462.93$ \\
\hline & Av. $\pm \mathrm{Se}$ & $1.007 \pm 0.12$ & $237.30 \pm 196.87$ & $4555.12 \pm 3658.87$ & 26.33 & --- \\
\hline & Day & $1^{\text {st }} \ldots .6^{\text {th }}$ & $7^{\text {th }} \ldots . .1^{\text {st }}$ & $6^{\text {th }} \ldots .1^{\text {st }}$ & $1^{\text {st }} \ldots 7^{\text {th }}$ & $1^{\text {st }} \ldots 7^{\text {th }}$ \\
\hline \multirow[t]{3}{*}{ Acetone } & Range & $0.400-1.851$ & $0.001-5.58$ & $1.23-28.55$ & $0.004-100$ & $1-5580$ \\
\hline & Av. $\pm \mathrm{Se}$ & $1.306 \pm 0.235$ & $0.003 \pm 0.834$ & $12.37 \pm 4.46$ & 28.61 & --- \\
\hline & Day & $6^{\text {th }} \ldots .1^{\text {st }}$ & $6^{\text {th }} \ldots .7^{\text {th }}$ & $7^{\text {th }} \ldots .2^{\text {nd }}$ & $2^{\text {nd }} \ldots . .7^{\text {th }}$ & $1^{\mathrm{st}} \ldots .7^{\mathrm{th}}$ \\
\hline \multirow[t]{3}{*}{ Ethanol } & Range & $0.462-2.145$ & $0.05-10.55$ & $2.03-119.56$ & $0.47-100$ & $1-25.12$ \\
\hline & Av. $\pm \mathrm{Se}$ & $1.426 \pm 0.219$ & $2.45 \pm 1.41$ & $27.73 \pm 15.71$ & 18.80 & --- \\
\hline & Day & $6^{\text {th }} \ldots .2^{\text {nd }}$ & $6^{\text {th }} \ldots . .1^{\text {st }}$ & $7^{\text {th }} \ldots . .1^{\text {st }}$ & $6^{\text {th }} \ldots . .1^{\text {st }}$ & $1^{\text {st }} \ldots . .7^{\text {th }}$ \\
\hline \multirow[t]{3}{*}{ Volatile oil } & Range & $0.601-1.434$ & $0.074-19.07$ & $1.181-2578.30$ & $0.003-100$ & $1-257.70$ \\
\hline & $\mathrm{Av} . \pm \mathrm{Se}$ & $1.029 \pm 0.113$ & $4.06 \pm 2.60$ & $341.23 \pm 361.84$ & 14.35 & --- \\
\hline & Day & $1^{\text {st }} \ldots . .5^{\text {th }}$ & $7^{\text {th }} \ldots . .1^{\text {st }}$ & $9^{\text {th }} \ldots . .1^{\text {st }}$ & $1^{\text {st }} \ldots . .7^{\text {th }}$ & $1^{\text {st }} \ldots . .7^{\text {th }}$ \\
\hline
\end{tabular}




\section{REFERENCES}

1. Abbot, W.S. 1925. A method of computing the effectiveness of an insecticide. J. Econ. Entomol. 18: 265-267.

2. Adebayo, T. and A.A. Gbolade. 1994. Protection of stored cowpea from Callosobruchus maculates using plant products. Insect Sci. and its Application, 15 (2): 185-189.

3. Anderson, B.A., R.T. Holman, L. Lundgren and G. Stenhagen. 1980. Capillary gas chromatography of leaf volatiles. A Agric. Food Chem. 28: 985-989.

4. Calvacanti, E.S.B., S.M. Morais, M.A.A. Lima and E.W.P. Santana. 2004. Larvicidal acivity of essential oils from Brasilian plant against Aedes aegypti L. memorias do Instituto Oswaldo Gruz. 99 (5): 541-544.

5. Dwivedi, S.C. and G. Seema. 2003. Toxicity evaluation of flower extract of Lantana camara on life cycle of Corcyra cephalonica. Indian J. Entomol. 65 (3): 330-334.

6. El-Hefny, A.S., O.M.M. El-Sahn and Sh.S. Yacoub. 2011. Effect of some plant extracts on citrus mealy bug Planococcus citro (Risso). Egypt J. Agric. Res. 89 (2): 511-519.

7. Finney, D.F. 1952. Probit Analysis. Cambridge University Press, London, 256 pp.

8. Freedman, B., L.J. Nouak and W.F. Kwolek. 1979. Abioassay for plant-derived pest control agent using the Eiropean corn borer. J. Econ. Entom. 72: 541-545.

9. Hewady, M.A.A., L.S. El-Sherif and A.M. Omar. 1994. Evaluation of four plant oils against newly hatched larvae of the cotton bollworms, Pectinophora gossypiella (saund) and Earias insulana (Boisd), (Lepidoptera : Noctuidae). Annals of Agric. Sci., Moshtohor, 32 (4): 2097-2104.

10. Inyang, Y.E. and S.O. Emosairue. 2005. Laboratory assessment of the repellent and antifeedant properties of aqueous extracts of 13 plants against the banana weevil, Cosmopolites sordidas German (Coleoptera : Curculionidae). Tropical and Subtropiral Agroecosystems, 5 (1): 33-44.

11. Litchfield, J.T. and F. Willcoxan. 1949. A simplified method of evaluating dose effect experiment. J. Phamacol, And Exp. There P. 96: 99-113.

12. Morsy, T.A., S.A. Mazyad and I,M.A. El-Aharkawy. 1998. The larvicidal activity of solvent extracts of three medicinal plants against third instar of Chrysomya albiceps. Journal of the Egyptian Soc. of Parasitology. 28 (3): 699-709.

13. Mukhtar, A., B.K. Gupta, R.S. Bhandari and M. Ahmed. 1991. Efficacy of some plant extracts against Ailathus web worm Attera fabriciella. Indian J. Foresty, 14 (1): 5-7. 
14. Pandey, U.K., A. Srivastava, C. Lekha, S. Ashok and A. Singh. 1983. Efficacy of certain plant extracts against brinjal aphid Aphis gossypii Glover. Indian J. Entomol. 45 (3): 313-314.

15. Pandy, N.D., L. Singh, Y.P. Singh and R.A. Tripath. 1987. Effect of certain plant extracts against Lipaphis erysimi Kalt. Under laboratory conditions. Indian J. Entomol. 49 (2): 238-242.

16. Rajapakse, R.H.S. and D. Ratnasekera. 2008. Pesticidal some selected tropical plant extracts agaist Callosobruchus maculates F. and Callosobruchus chinensis L. (Coleoptera : Bruchidae). Tropical Agricultural Research, 11 (1).

17. Reddy, G.V.P., K.C.D. Urs, O.P.A. Grawal and D. Shashi. 1991. Antifeedant and repellent activity of some indigenous plant extracts against the furniture beetle, Sinoxylon sudanicum Lesene (Coleoptera : Bostrychidae). Biodeterioration of cultural property. Proceeding of the International Conference India, 173-185.

18. Shenge, K.C., I.I. Urah and R.S. Adamu. 2002. Effect of different lemongrass powders on Sitophilus zeamais moth infesting stored maize grain. J. sustainable Agric. and the environment. 4 (1): 23-28.

19. Sun, Y.P. 1950. Toxicity index on improved method of comparing the relative toxicity of insectivides. J. Econ. Entomol., 43: 45-53. 


\section{سمية بعض المستخلصات النباتية لخنفساء الخشب الساحقة}

\section{Sinoxylon sudanicum Lesne}

محمد صابر أحمد

عبد الغنى محمد بط

معهز بحوث وقاية النباتات ـ مركز البحوث الزراعبة ـ الدقى · جيزة

أجريت هذه الدراسة لأول مرة في مصر بغرض تقييم سمية بعض المستخلصات النباتية على

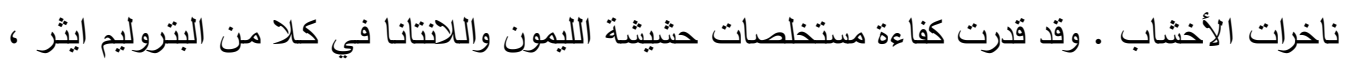

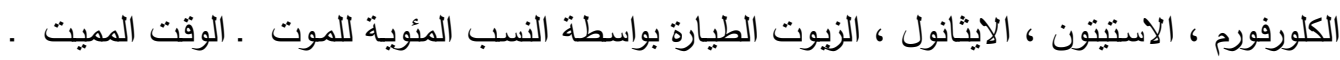

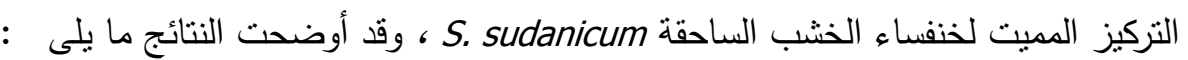

* يـزداد متوســ النسـب المئويـة للمـوت بزيـادة تركيـز المستخلصـات المختلفـة وقـــــــلت خمســة مجموعات احصائية لكلا من مستخلصات حشيشة الليمون واللانتانا ـ وضمت المجموعة الأعلى تأثيراً

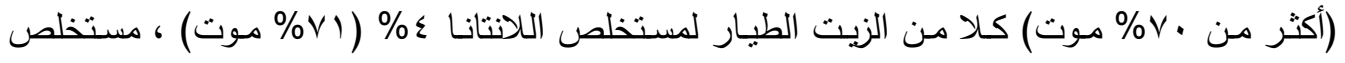

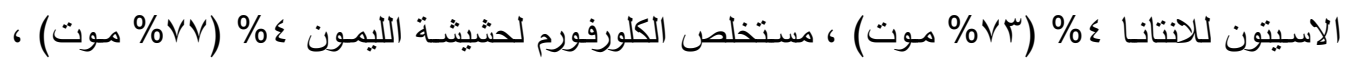

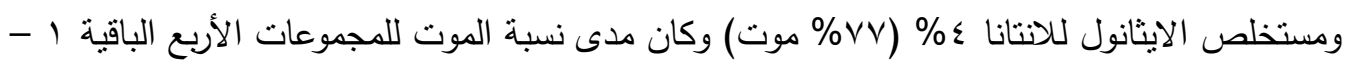

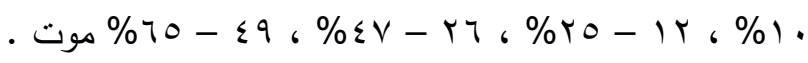

* اختلف الوقت الـلازم لقتل نصف التعداد المعامل (LT $)$ تبعـا لاختلاف المستخلصـات وتركيزاتها

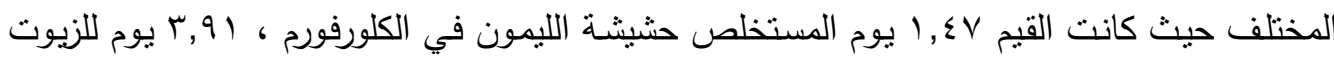

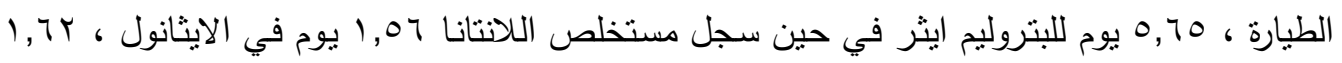

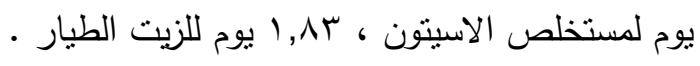

* اختلفت قيم التركيزات اللازمة لقتل نصف التعداد تبعا للمستخلصات المختلفة فقد كانت أقل قيم LC50

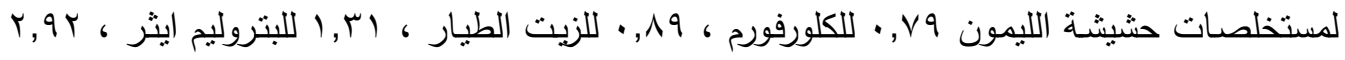

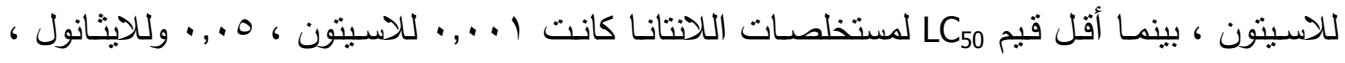

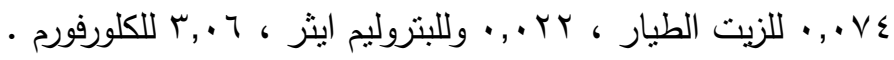

